\title{
A Sociocultural Framework to Analyse M-Learning Options for Early Childhood Development (ECD) Practitioner Training
}

\section{Susanna Oosthuizen}

Chief Operating Officer, Penreach; and Master's student, Department of Childhood Education, University of Johannesburg

iD https://orcid.org/0000-0002-7691-3362

\section{Nicky Roberts \\ Associate Professor, Department of Childhood Education, University of Johannesburg \\ (iD https://orcid.org/0000-0002-1910-0162}

\begin{abstract}
This article, a contribution to m-learning (mobile learning) research, centres on the motivation for, and development of, a suitable framework to analyse m-learning options for early childhood development (ECD) practitioners. Grounded in a sociocultural learning perspective, the framework was developed as part of a larger study into the feasibility of $\mathrm{m}$-learning for ECD practitioners in the Penreach professional development programme in Mpumalanga Province, South Africa. Analysis of existing frameworks enabled the development of a new, modified framework to suit the Penreach context. Here we unpack the framework and explain its development. The new, modified framework aims to assist researchers, developers, and implementers by prompting consideration of five sociocultural learning features associated with $\mathrm{m}$-learning in ECD, namely: device access, data affordability, authenticity, collaboration, and personalisation.
\end{abstract}

\section{Keywords}

m-learning, mobile learning, early childhood development (ECD), professional development, training, sociocultural learning

DOI: https://doi.org/10.23962/10539/32209

\section{Recommended citation}

Oosthuizen, S., \& Roberts, N. (2021). A sociocultural framework to analyse m-learning options for early childhood development (ECD) practitioner training. The African Journal of Information and Communication (AJIC), 28, 1-20.

https://doi.org/10.23962/10539/32209

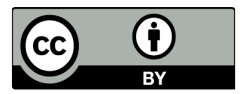

This article is licensed under a Creative Commons Attribution 4.0 International (CC BY 4.0) licence: https://creativecommons.org/licenses/by/4.0 


\section{Introduction}

\section{Early childhood development (ECD)}

In the past decade, international and African-based research studies and policy frameworks have highlighted the significance of early childhood development (ECD). The World Bank's 2018 World development report found that foundational skills in early childhood are essential for future learning, and that effective ECD interventions are necessary to significantly improve (especially poor) children's ability to learn (World Bank, 2018, p. 114). The potential that quality ECD has for the improvement of the learning outcomes of poor children is of critical importance in South Africa, where the majority of children under six live in poverty (Ashley-Cooper et al., 2012; Hall, 2010). Prominent authors in the field of ECD in South Africa concur that more trained ECD practitioners are required in order to achieve a universal and quality ECD for all children (Ashley-Cooper et al., 2012; Biersteker et al., 2008).

South Africa's National Development Plan 2030 (NPC, 2012) and National Integrated Early Childhood Development Policy (RSA, 2015) mention the need to improve access to quality ECD for poor children. The latter encapsulates the vision for ECD in South Africa as follows: "[a]11 infants, young children and their families in South Africa [should] live in environments conducive to their optimal development" (RSA, 2015, p. 48).

The recent National Income Dynamics Study - Coronavirus Rapid Mobile Survey (NIDS-CRAM) survey found that, in 2021, about 36\% of South African families with children under the age of six reported a child attending an ECD centre (other than Grade R) (Wills \& Kika-Mistry, 2021). This reflects a recovery in ECD attendance to almost the pre-pandemic levels of 39\%, following significant disruptions due to COVID-19 in 2020 (Wills \& Kika-Mistry, 2021). May et al. (2020) report that poverty, unemployment, and hunger rose dramatically under the COVID-19-related "hard lockdown", with $47 \%$ of South African households running out of money to buy food in May/June 2020, while child and adult hunger increased to 15\% and 22\% respectively.

Less than half of South African children under the age of six access any form of early learning (Stats SA, 2016, p. 64). The most recent data indicates that of the 7 million children aged 0 to 5 years old, only 3.3 million are accessing some kind of early learning programme. Within this cohort, $69 \%$ of 3 - to 5 -year-olds attend a learning programme or Grade $\mathrm{R}$, while only $30 \%$ of 0 - to 2 -year-olds attend such programmes, i.e., $70 \%$ of 0 - to 2 -year-olds are cared for exclusively at home (Thorogood et al., 2020).

A study by the Department of Basic Education (DBE), the Department of Social Development (DSD), and UNICEF identified a shortage of qualified practitioners 
to meet the demands of ECD provision in South Africa (DBE, DSD \& UNICEF, 2011, p. 87) and recommended the preparation of more skilled practitioners to deliver in poor communities. This skills gap in ECD was also highlighted in a 2014 audit of the ECD sector by the Department of Social Development (DSD, 2014), which reported both a shortage of qualified practitioners to meet the demands of ECD (2014, p. 134) as well as a skills gap among current working practitioners (2014, p. 94).

\section{M-learning}

At the same time, the potential offered by mobile learning (m-learning) is receiving increasing attention in South Africa and internationally. Prompted by the rapid uptake of mobile technology in Africa and the Middle East, UNESCO undertook a study in 2012 on the potential of m-learning to improve teaching practice in these regions (Isaacs, 2012). That study found that the use of such technology can influence the supply of qualified teachers in remote areas (Isaacs, 2012, p. 11). Subsequently, South African and international researchers collaborated to develop a definitive m-learning curriculum framework applicable to South Africa (Botha et al., 2012). The framework's authors found that "teacher development is one of the most manageable and cost-effective ways of using mobile technologies to break into the cycle and the system of Education" (Botha et al., 2012, p. 2). A literature review by Alawani and Singh (2017), aimed at establishing a conceptual framework for mobile learning in teacher professional development in the United Arab Emirates, points to the potential of m-learning as a complementary method to enhance teacher professional development, especially due to its ability to reach remote areas and provide ubiquitous access to content, expertise, and peer-based support (2017, p. 150). Both the Botha et al. (2012) and Alawani and Singh (2017) studies recognise the potential value of $\mathrm{m}$-learning to support and possibly scale educator training.

Insofar as educator training is concerned, pre-grade R ECD practitioners have traditionally been considered a poor audience for digital learning. Benner and Pence (2013) suggest that this is due to negative perceptions of their education levels, their ability to access technology, and their willingness to take up non-traditional forms of learning. The South African Department of Basic Education (DBE) (2018) has developed and invested in a Professional Development Framework for Digital Learning. The framework, however, focuses intensively on curriculum and school-based systems to support integration of digital skills, and omits attention to pre-grade $\mathrm{R}$ (the pre-school reception year) ECD.

\section{Lack of research on m-learning in pre-grade $R$ context in South Africa}

Despite the increased interest in $m$-learning and ECD respectively, there is a marked lack of research on m-learning in ECD, especially in the African and South African context (Roberts \& Spencer-Smith, 2019). Botha et al. (2012) found that there existed only limited local examples of m-learning to draw from for South African 
implementation. In addition to this general dearth of local studies on m-learning, few studies to date have focused on pre-grade $\mathrm{R}$ practitioner development and m-learning.

A search of the LearnTechLib database (previously EdITLib) shows a telling decline in search results when drilling down from "m-learning" (47,424 articles), to "m-learning and ECD" (43 articles) to "ECD and m-learning and Africa" (6) and "ECD and m-learning and South Africa" (5). None of the African studies focused on pre-grade R practitioner development. A search of the South African Journal of Childhood Education $(S A J C E)^{1}$ database yielded eight results related to "m-learning and ECD" and none of these pertained to pre-grade R practitioner skill training. Roberts and Spencer-Smith (2019) point to a 2016 special edition of the SAJCE, in which $\mathrm{m}$-learning was notably absent from the interventions listed as useful in improving the instructional practice of ECD educators in the African context.

Chee et al. (2017) identify a dearth of research about m-learning in ECD in a global meta-analysis of 144 peer-reviewed articles on m-learning from six eminent journals spanning five years $(2017$, p. 118). No sample in any of the studies was from a pre-primary educational setting and no studies pertained to ECD practitioner skills training. Trucano (2013), reporting for UNESCO, hails South Africa as a leader in Africa with regard to "cutting-edge" $\mathrm{m}$-learning initiatives and research. Yet, Trucano (2013) only refers to two interventions to support this claim: the Yoza Project ${ }^{2}$ and Dr Maths, ${ }^{3}$ both aimed at children above five years of age. Botha and Vosloo (2008) present four examples of medium- to large-scale m-learning interventions in South Africa, none of which is ECD-focused: Dr Math, M4Girls, Imfundo yami/ yethu, and Angles on MXit. More recent and local studies that focus on technology use in teacher development exclude pre-Grade R ECD practitioners. For example, Herselman and Botha (2014), working on mobile tablet interventions, report on their learnings from interventions in rural schools (grades $\mathrm{R}$ to 12 ) in the South Africa's Eastern Cape Province. This study does not include the pre-Grade R level. Isaacs, Roberts, Spencer-Smith and Brink (2019) report on a professional development intervention for Grade $\mathrm{R}$ practitioners which included minimal use of mobile phones (via WhatsApp). While this study includes consideration for ECD centres, this is only at the Grade R level and not at the pre-Grade R level.

On the basis of the above, there is a clear need for empirical research on the integration of m-learning into pre-Grade R training and development in the South African context. There is also a paucity of literature that attempts to provide a theoretical

$1 S A J C E$ is the only South African journal with an ECD focus.

2 See https://m4lit.wordpress.com

3 See https://drmaths.com 
framework to examine m-learning in different contexts (Kearney et al., 2012). According to these authors, educational research has up to now not clearly defined which pedagogies are most suitable for m-learning.

The gap in research on the application of m-learning for skills training in pre-Grade R ECD, especially in South Africa, is marked and provided one motivation for this research. The other motivation was more localised and practical: the need to make ECD practitioners at the pre-Grade $\mathrm{R}$ level part of the dialogue about if and how $\mathrm{m}$-learning can contribute to their skills training. This required a suitable framework to analyse m-learning options within the specific sociocultural environment of Penreach pre-Grade R ECD practitioner training in Mpumalanga Province, South Africa.

\section{Conceptual framing}

In this section, we set out our conceptual framework, making explicit our adoption of a sociocultural perspective on learning, and explaining what this means. We then argue (1) that a sociocultural perspective is relevant to educator professional development; and (2) that a sociocultural perspective is relevant to assessments of m-learning options.

\section{Sociocultural perspective on learning}

The approach to learning adopted in the broader study, and hence in this article, is a sociocultural perspective, which acknowledges the reciprocal effect that learning and learning tools have on each other and which we argue is appropriate for assessing $\mathrm{m}$-learning options for Penreach pre-Grade R ECD practitioner training.

A sociocultural perspective recognises the influence that circumstances and culture have on an individual's behaviour, specifically related to their learning. The sociocultural perspective also proposes that knowledge is co-constructed through interaction (Conole, 2004; Eun, 2008; Kelly, 2007; Vygotsky, 1978). Sociocultural theory emanates from the work of Vygotsky (1978), who proposed that learning is a socially mediated process where learners (adults and children) are jointly responsible for learning, and that learning is optimised when in the Zone of Proximal Development (ZPD). In Vygotskian thinking, the origin of knowledge construction lies in social interaction and not in an individual mind. Knowledge is co-constructed, and this process is mediated by tools and artefacts from a specific environment and cultural context (Shabani, 2016).

Eun (2008) argues that a sociocultural perspective is relevant to educator professional development and applies a sociocultural perspective as a unified theory to explain the most effective mechanism for educators to acquire knowledge and skills (2008,p. 135). Eun (2008) defines four key theoretical concepts from Vygotsky's work, namely social interaction, internalisation, mediation, and psychological systems. 
According to Eun (2008), social interaction is a key concept for professional development, and manifests through workshops, study groups, seminars, and mentoring, where knowledge is developed through interacting with others. Shabani (2016) supports this assertion, and describes study groups as collaborative opportunities to discuss common challenges and co-construct knowledge as solutions. Internalisation in Eun's conception takes the form of self-study and individual activities. With regard to mediation Eun (2008) describes indirect or mediated activity as necessary for any development to occur after the initial professional development experiences. Mediated activity uses three mediators, namely tools (materials, resources), signs (newsletters and journals), and other human beings. Last, the psychological systems described by Eun focus on changing the attitude and instructional practice of educators (2008, p. 144).

The work of Eun (2008), Shabani (2016) and Alawani and Singh (2017) grounds educator professional development in sociocultural theory, and regards professional development as largely intramental (occurring within the mind) and social (occurring among people). It also describes the most effective social interaction for professional development as that which takes place within the ZPD, where it is easiest to collaborate and build knowledge. This implies that the "when" and "how" of ECD professional development are important, including the when and how of using m-learning. Eun (2008), like Shabani (2016), suggests that, from a sociocultural standpoint, educator professional development is most effective when it is grounded in practice. In addition, Eun (2008) asserts that professional development is also most effective in constructs such as "professional learning communities" where educator-learners have shared goals and can collaborate to co-construct knowledge that is relevant to their shared context (Eun, 2008, p. 146).

Kelly (2007) proposes that the theoretical work on the factors that contribute to the learner's sociocultural environment points to four mutually interacting core elements (see Figure 1): environment, individual, culture, and historical development. 
Figure 1: Four core elements of sociocultural theory (Kelly, 2007)

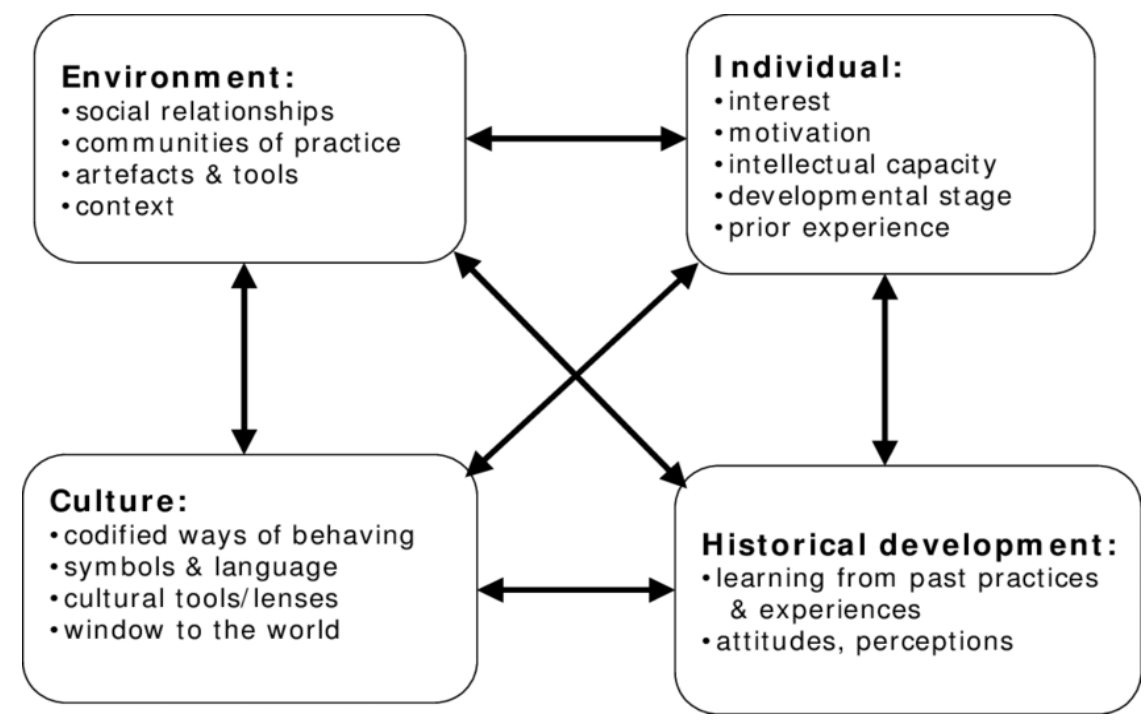

Source: Kelly (2007, p. 56)

\section{Relevance of sociocultural perspective on m-learning}

Adopting a sociocultural perspective on m-learning is appropriate within the South African context because it aligns with the Department of Basic Education's (2018) aforementioned Professional Development Framework for Digital Learning, which notes that:

It is necessary for teacher professional development to specifically address how digital tools and resources can support teaching and enhance learning in different subjects in a wide range of socio-economic contexts that teachers encounter in South Africa. (DBE, 2018, p. 10).

Traxler (2007) proposes that research on m-learning should develop concepts emanating from the learner perspective and not the perspective that forefronts technology as the driving force of the learning experience. Traxler (2007) points to the preponderance of frameworks for m-learning that focus more on technology than on pedagogy, and states:

So mobile learning is not about 'mobile' as previously understood, or about 'learning' as previously understood, but part of a new mobile conception of society. (This may contrast with technology enhanced learning or technology supported, both of which give the impression that technology does something to learning.) (Traxler, 2007, p. 5). 
Koole (2009) proposes a framework for rational analysis of mobile education (FRAME) (see Figure 2), in which m-learning is in terms of three interacting aspects: device, learner, and social context (Koole, 2009, p. 27).

Figure 2: FRAME model for m-learning (Koole, 2009)

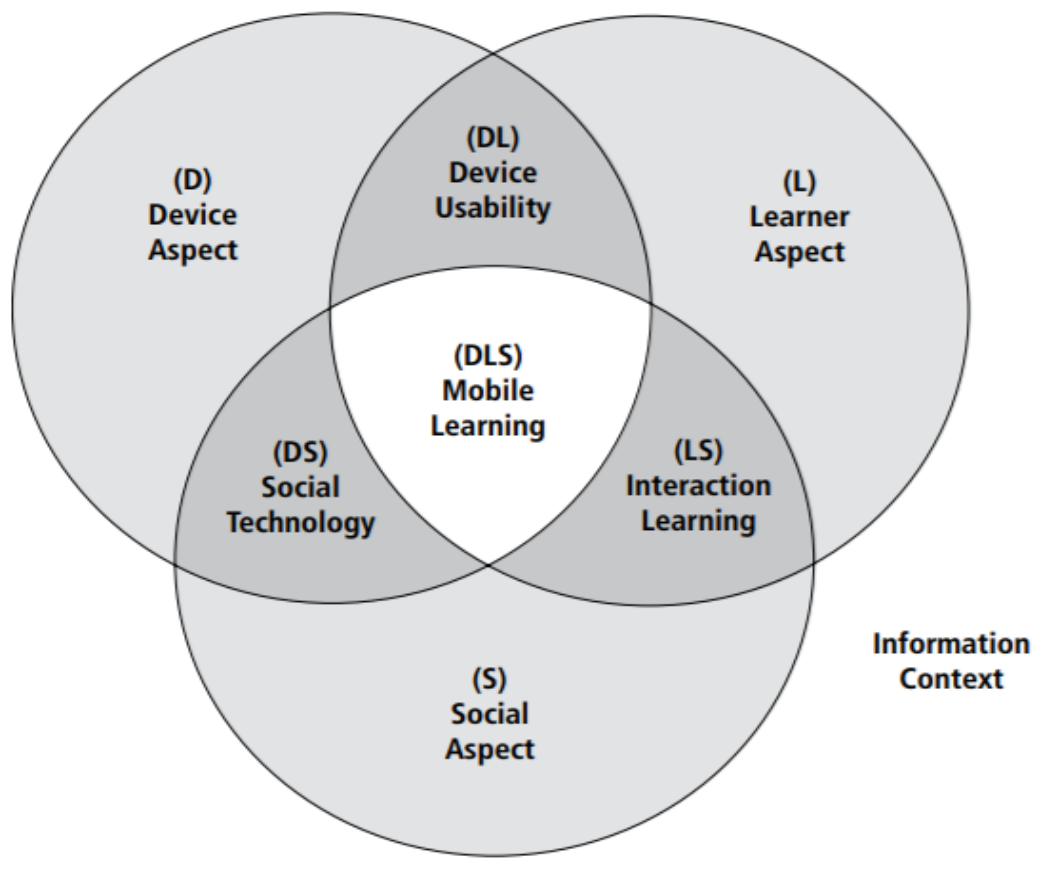

Source: Koole (2009, p. 27)

Koole's (2009) FRAME model resonates with Traxler's view through its inclusion of the social context as one of the three key interacting spheres to understand how $\mathrm{m}$-learning manifests. And by describing the interaction between spheres, it aligns with Traxler's view that technology does not influence learning in a one-directional way. Making use of the ideas of Vygotsky (1978), Koole (2009) posits that the ideal $\mathrm{m}$-learning environment manifests where mediation exists, through which "the nature of the interaction itself changes as learners interact with each other, their environments, tools, and information" (Koole, 2009, p. 39). This is clearly a sociocultural perspective on m-learning, in that it views learning as a process of interactions that take place within a learner's social and cultural context. The work of Traxler (2007) and Koole (2009) firmly establishes the sociocultural context as critical in understanding m-learning. 


\section{Research design}

The larger Penreach study, of which the research outlined in this article was part, assessed the feasibility of three different $\mathrm{m}$-learning applications before choosing one for use to support pre-Grade R ECD practitioners. In order to achieve this aim, a suitable framework for analysing $\mathrm{m}$-learning options for professional development was required, and thus the conceptual exploration covered by this article was conducted.

\section{Research setting}

The general research setting is the ECD practitioner training landscape in South Africa, which has been studied by the likes of Biersteker et al. (2008), Ashley-Cooper et al. (2012), Feza (2013), and the Department of Social Development (DSD, 2014). Evident from these studies is the need for ECD skills training to move away from a distance-based and theoretically oriented training, to training that is practical, contains practical demonstrations, is embedded in the real work of the practitioner, provides sufficient support during and after training, and assists practitioners to provide quality services where they operate.

The specific setting for the Penreach study (hereafter "the Penreach context") is a rural context where pre-Grade R ECD practitioners are supported in their ongoing professional development. These pre-Grade $\mathrm{R}$ practitioners are working in severely under-resourced environments in Mpumalanga Province, often earning less than minimum wage. These educators' socio-economic context influences their ability to use $\mathrm{m}$-learning. Therefore, as is seen later in this article, the cost of owning a smart device and the cost of mobile network access for m-learning were considered to be directly related to feasibility.

\section{Research purpose}

This article describes the process undertaken to develop a new, modified sociocultural framework to assess m-learning tools and select the one most suitable for use by ECD practitioners in the Penreach project in rural Mpumalanga.

\section{Research questions}

The two research questions guiding the research outlined in this article were:

- What are the available frameworks to assess m-learning options for professional development of educators that may be relevant to the Penreach context?

- Which framework, or combination/adaptation of frameworks, is suitable for the task of assessing the feasibility of three m-learning applications for Penreach? 


\section{Methods}

A scan of the literature was conducted and several conceptual and analytical frameworks were consulted. Studies and articles were identified that present seminal findings on, or well-received theories about, m-learning. The research problem spanned knowledge areas of "education", "early childhood development", "practitioner training", "skills training", "practitioner professional development", "technology", "learning technology", and "mobile learning". With this in mind, Boolean searches were conducted using the LearnTechLib database, the Journal of Research in Learning Technology, the South African Journal of Childhood Education (SAJCE), and the UNESCO database for papers presented at its annual Mobile Learning Week.

The research questions simultaneously demanded knowledge of the South African ECD practitioner training context in general, and of the Penreach context in particular. Without this, the relevance or suitability of any framework on m-learning and educator development could not be judged. For the general context, literature on South African research in the ECD and m-learning fields was consulted. For determining the Penreach context, this study had the benefit of the detailed contextual knowledge of this article's lead author Oosthuizen, who holds a senior position in Penreach's professional development programme. Further contextual knowledge was obtained through an empirical study conducted by Oosthuizen, which included surveys completed by all the ECD practitioners, and structured interviews with four practitioners during a follow-up site visit. The findings from the empirical study are not the subject of this article. Suffice to note that the planning and preparation for that study deepened the ability of this article's lead author to judge the suitability and relevance of theoretical frameworks to the Penreach context.

\section{Findings}

In discussing the findings we reflect on each of the two research questions in turn.

\section{Research question 1: Available framerworks}

- What are the available frameworks to assess m-learning options for professional development of educators that may be relevant to the Penreach context?

As we consulted the literature it became clear that m-learning frameworks were neither plentiful nor standardised, and that m-learning tools tended to omit a focus on pedagogy. Danaher et al. (2009) argue that there seems to be a high demand for tools and technology in m-learning, but less support for research that relates these tools and techniques to an underlying pedagogy. Given the continuous advancement of mobile technology, Danaher et al. (2009) suggest that researchers should push the pedagogy agenda, and learn from one another so that m-learning is understood according to its value for learning (Danaher et al., 2009, p. 3). This view echoes the Laurillard (2002) view that "technology is looking for a problem to solve in education", and that a technology focus promotes the misleading notion that the technol- 
ogy precedes or leads education. Laurillard (2002) argues that the better approach is to start by identifying the problem in education and then selecting and applying an m-learning approach that fits the pedagogical needs.

Roberts and Spencer-Smith (2019) lament the lack of comparable or standard frameworks in studies on m-learning, noting that the paucity of standardised frameworks makes it difficult to draw meaningful comparisons between findings (Roberts \& Spencer-Smith, 2019, p. 3). Roberts and Spencer-Smith (2019) propose adaptation or improvement of their own modified analytical framework for studies in the $\mathrm{m}$-learning field, in order to establish "commonly agreed metrics and approaches, to measure and reflect on efficacy" (Roberts \& Spencer-Smith, 2019, p. 10). Isaacs, Roberts and Spencer-Smith (2019) apply the Roberts and Spencer-Smith (2019) framework to their analysis of four m-learning pilots in Africa.

Our scan of the literature identified four frameworks pertaining to m-learning which we found had potential relevance to the Penreach context:

- the Alawani and Singh (2017) "smart mobile learning conceptual framework for professional development", which emphasises contextualisation, social aspect, and personalisation;

- the Laurillard (2002) "conversational framework", which offers a distinct focus on pedagogy;

- the Kearney et al. (2012) "pedagogical framework for m-learning", which draws on and adapts the Laurillard (2002) framework; and

- the Roberts and Spencer-Smith (2019) “analytical framework for describing $\mathrm{m}$-learning interventions".

We now briefly describe each framework in turn.

Alawani and Singh (2017) "smart mobile learning" framework

The Alawani and Singh (2017) framework reverberates with elements of Eun (2008) and Shabani (2016). Alawani and Singh (2017) conducted a study about the experience of m-learning by teachers in a professional development context in the United Arab Emirates. The research found that effective m-learning in professional development is dependent on its contextualisation. Equally important and included in their framework are the social aspects of professional learning and the fact that learning at this level needs to be personalised (2017, p. 156).

\section{Laurillard (2002) "conversational" framework}

Laurillard's (2002) framework has a distinct focus on pedagogy, in that it defines the pedagogy required for optimal learning. More specifically, it consists of a flow of questions that interact in an iterative way. The framework was designed to be used in learning design. The pedagogical soundness of the learning design can be measured by how many of the questions in the framework can be answered. Laurillard 
(2002) describes the application of the framework as relevant to m-learning design. A pedagogically sound m-learning design would, according to the conversational framework, include aspects of collaboration, communication, and sharing (Laurillard, 2002). Laurillard's (2002) conversation framework suggests that from a pedagogical perspective, the learner's practice is improved if knowledge outputs can be shared with peers. In addition, through peer discussion, reflection can occur, which enhances the learner's own conceptual understanding of the topic. Laurillard (2002) found that in m-learning, the affective motivation for learning increases with the opportunity to communicate with others. Finally, an optimal learning experience is created where information and artefacts can be shared (Laurillard, 2002, p. 18).

\section{Kearney et al. (2012) "pedagogical framework"}

In the development of their pedagogical framework, Kearney et al. (2012) draw on insights from Traxler (2007), Koole (2009), and Laurillard (2002). Kearney et al. (2012) attempt to include the most important social characteristics and relationships that affected m-learning. During their research process, Kearney et al. (2021) identified "time-space" as integral to m-learning, contributing a new dimension to the study of m-learning. They position "time-space" as central in their framework, with $\mathrm{m}$-learning positioned as transcending the traditional limitations of formal learning by making it possible to learn anywhere and anytime. By overcoming the spatial and temporal features of classroom-based learning, "learning time" in m-learning becomes socially negotiated. Participants in the learning experience can agree where and when interaction takes place, without negatively affecting the learning itself (Koole, 2009). According to Kearney et al. (2012), one must accept that the pedagogy of m-learning takes place within this "malleable space-time context", and this should be central to understanding m-learning (2012, p. 4).

Kearney et al. (2012) test what they see as eight key features of m-learning: portability, social interaction, contextual sensitivity, connectivity, individuality, usability, learning, and integration into practice. These features emerged from the work of Koole (2009) and Klopfer et al. (2002). The eight features are arranged in different relationships to one another to form a conceptual framework. Three versions of this framework were tested over the course of 18 months with eight academics in an Australian university and eight trainee teachers in the UK who used m-learning as part of their professional training. The final framework that emerges from their research contains three main features: collaboration, authenticity, and personalisation. The authors posit that these three features, along with six sub-scales, would be effective in analysing the pedagogy behind m-learning (see Figure 3). 
Figure 3: Kearney et al. (2012) framework

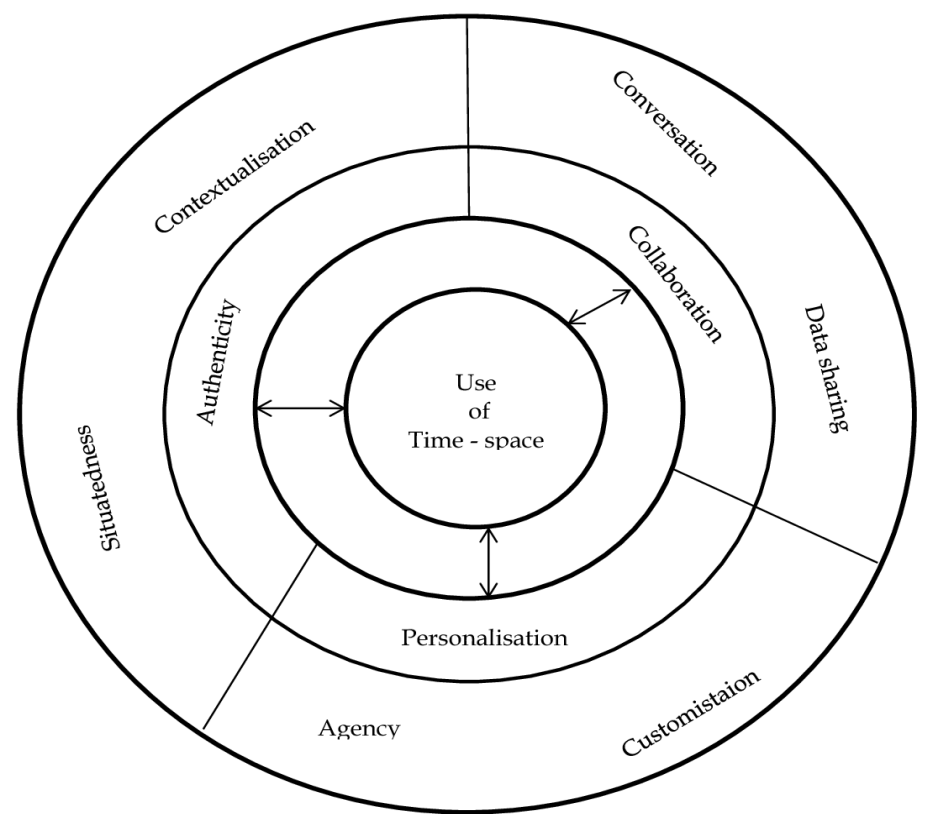

Source: Kearney et al. (2012, p. 8)

Collaboration describes learning through interaction with others and mediated by tools (Conole, 2004; Laurillard, 2002; Shabani, 2016). It is therefore included as one of the key features in the Kearney et al. (2012) framework. Authenticity refers to how learning practices are similar to what a learner needs to do in the "real world" (Kearney et al., 2012,p. 9). Authentic learning is considered one of the most effective ways to ensure so-called "deep learning" and is pedagogically relevant (Herrington \& Oliver, 2001). In a study on innovative learning in the 21st century, the OECD (2017) highlights authentic and collaborative learning as critical to optimal digitally enabled learning environments. The personalisation feature is developed by Kearney et al. (2012) from the body of research about mobile tools and learner agency, most notably that of Klopfer et al. (2002) and Pachler et al. (2010). It describes the ability of the learner to form their own learning experience based on their social context and own needs.

Roberts and Spencer-Smith (2019) framework

Working from an initial model by Pouezevara and Strigel (2012) that puts forward three m-learning spectra, the Roberts and Spencer-Smith (2019) framework adds three additional spectra for a total of six. The three spectra set out by Pouezevara and 
Strigel (2012) are:

- learning spectrum (between formal or informal);

- kinetic spectrum (between static and mobile); and

- collaboration spectrum (between individual and group).

Each of the three Pouezevara and Strigel (2012) spectra is non-binary, meaning that $\mathrm{m}$-learning occurs along the spectrum between the two possibilities.

To take account of the resource-constrained environments prevalent in South Africa, Roberts and Spencer-Smith (2019) add device access and data affordability spectra (see Figure 4). International and local studies have confirmed the importance of access and affordability elements in m-learning delivery (Benner \& Pence, 2013; Ebner \& Grimus, 2013; Nedungadi \& Raman, 2012). The device access spectrum ranges from m-learning that is designed or used with free devices provided to learners to a situation where learners need to bring their own device (i.e., bring your own device, or BYOD). Within this range, different permutations of learning design can manifest. For instance, learners can be required to bring their own devices but may also receive a subsidy towards monthly device costs. The data affordability spectrum can range from scenarios where mobile data is provided or subsidised to situations where learners need to pay all of their own data costs.

Figure 4: Roberts and Spencer-Smith (2019) framework

\section{M-Learning Configurations}

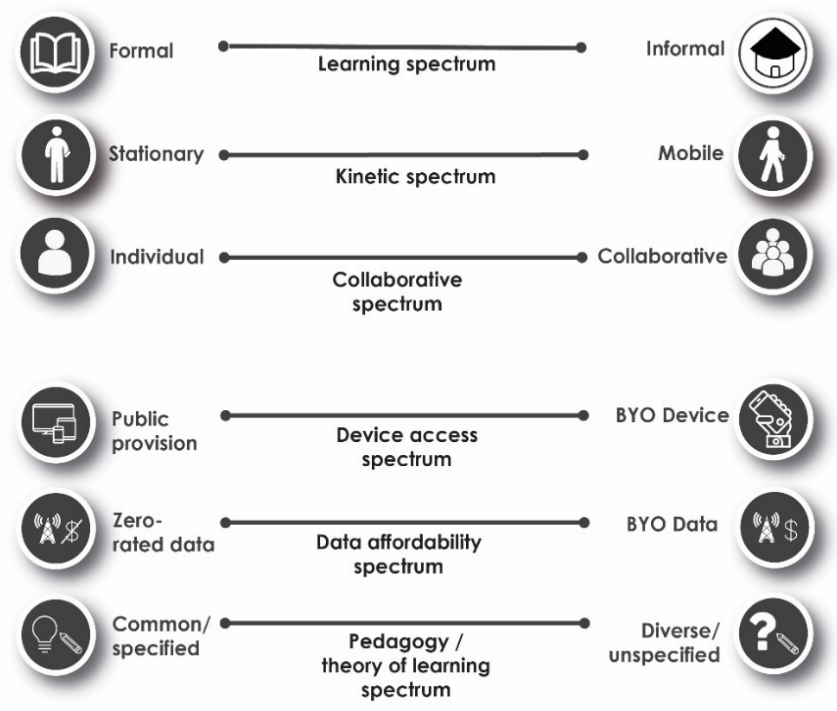




\section{Source: Adapted from Roberts and Spencer-Smith (2019, p. 4)}

Finally, Roberts and Spencer-Smith (2019) add pedagogy/theory of learning as a spectrum, with "a well-defined and articulated theory of learning" at one end of the spectrum, and "no articulation of learning theory" at the other end. In adding this spectrum to their framework, Roberts and Spencer-Smith (2019) seek to take account of the concerns raised by Danaher et al. (2009) and Laurillard (2002) regarding under-emphasis on pedagogy in some approaches to m-learning.

\section{Research question 2: Framerwork suitable for Penreach}

- Which framework, or combination/adaptation of frameworks, is suitable for the task of assessing the feasibility of three m-learning applications for Penreach?

The framework we found to be suitable for assessing Penreach m-learning applications incorporates key features from both the Kearney et al. (2012) and the Roberts and Spencer-Smith (2019) frameworks. It is firmly located within a sociocultural learning perspective.

All three components of the Kearney et al. (2012) framework-collaboration, authenticity, and personalisation - are included in the framework. With respect to the Roberts and Spencer-Smith (2019) framework, its collaborative spectrum was already represented in the Kearney et al. (2012) framework, and it was determined that the learning spectrum could be left out as it was not foregrounded in this study. (ECD skills training in the Penreach programme, and other similar programmes, is voluntary, non-accredited, and not part of a formal training curriculum. Learning takes place through workshops, with the application of newly acquired skills in the workplace. The m-learning setting was therefore already defined. The m-learning could be done at home, at work, or during the Penreach workshop, and none of these configurations was considered to have had an impact on the feasibility.)

The kinetic spectrum, adopted by the Roberts and Spencer-Smith (2019) framework from Pouezevara and Strigel (2012), was also not included, because the degree to which Penreach practitioners were required to sit or perform activities while using $\mathrm{m}$-learning was not considered important in terms of feasibility. And the Roberts and Spencer-Smith (2019) pedagogy/theory of learning spectrum was included because it was felt that Penreach had already explicitly adopted a sociocultural perspective.

It was determined that the Roberts and Spencer-Smith (2019) device access and data affordability spectra were highly relevant given Penreach's focus on a resource-constrained environment. The resulting framework (see Figure 6) comprises: collaboration, authenticity, and personalisation. 


\section{Figure 6: Framework for assessment of Penreach m-learning applications}

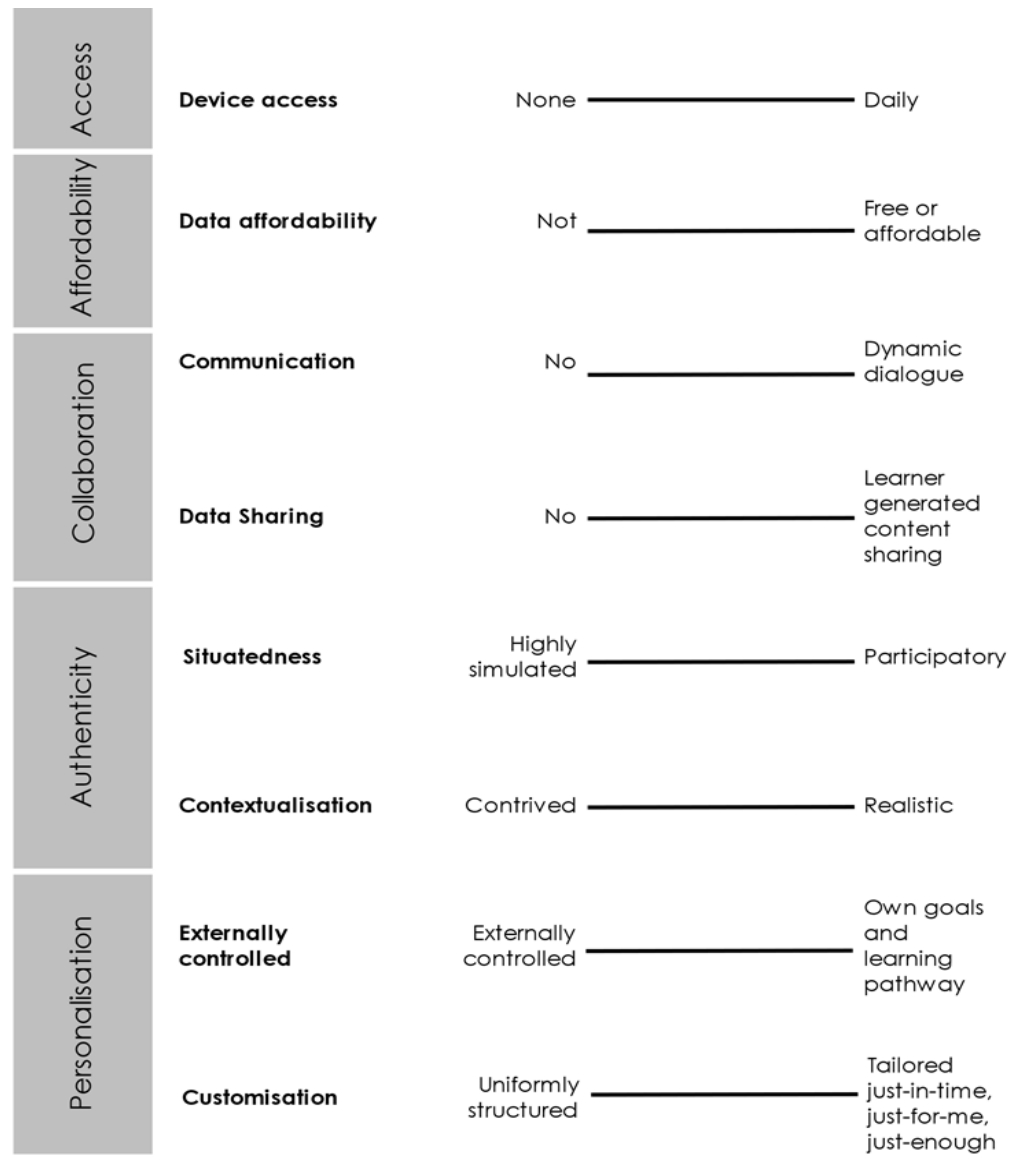

\section{Conclusion}

The need for a framework to assess m-learning applications in ECD was identified as part of a larger study into the feasibility of this form of learning in the South African ECD training context. First, the dearth of research about $\mathrm{m}$-learning in pre-Grade $\mathrm{R}$ practitioner training was recognised. Existing research did, however, allow for the development of a conceptual frame for analysing the feasibility of m-learning in the ECD training context. We adopted a sociocultural perspective for the training of ECD practitioners, recognising the reciprocal influence between the practitioner and the environment as part of the learning process. Particularly useful was the initial research into m-learning as a field by Traxler (2007), Koole (2009), and Laurillard (2002), which locates m-learning in the realm of sociocultural learning. 
Further exploration allowed us to consider different existing sociocultural frameworks for m-learning. Based on this analysis, we determined the need for a new, modified framework. Elements of recent frameworks developed by Kearney et al. (2012) and Roberts and Spencer-Smith (2019) were combined to develop a sociocultural learning framework that conceives of feasible m-learning in ECD as featuring device access, data affordability, authenticity, collaboration, and personalisation.

In the South African ECD context, practitioners operate in environments where no or little subsidy exists for accessing m-learning devices and data. In addition to these issues of access and affordability, the highly practical and situated work of educating young children requires a learning environment for practitioners that enables collaborative, authentic, and personalised learning. The modified analytical framework that incorporates these sociocultural dimensions is intended for use by researchers and implementers when considering the use of $\mathrm{m}$-learning in ECD training-including $\mathrm{m}$-learning in the pre-Grade $\mathrm{R}$ training contextin under-resourced contexts.

\section{References}

Alawani, A. S., \& Singh, A. D. (2017). A smart mobile learning conceptual framework for professional development of UAE in-service teachers. International Journal of Management and Applied Research, 4(3), 146-165.

https://doi.org/10.18646/2056.43.17-012

Ashley-Cooper, M., Atmore, E., \& Van Niekerk, L. (2012). Challenges facing the early childhood development sector in South Africa. South African Journal of Childhood Education, 2(1), 120-139. https://doi.org/10.4102/sajce.v2i1.25

Pachler, N. Cook, \& Bachmair, B., (2010). Appropriation of mobile cultural resources for learning. International Journal of Mobile and Blended Learning, 2(1), 1-211. https://doi.org/10.4018/jmbl.2010010101

Benner, A., \& Pence, A. (2013). From e- to m-learning: Feasibility for an African-delivered tertiary program. E-Learning and Digital Media, 10(1), 13-21.

https://doi.org/10.2304/elea.2013.10.1.13

Biersteker, L., Dawes, A., \& Irvine, M. (2008). Scaling up early childhood development (ECD) (0-4 years) in South Africa. What makes a difference to child outcomes in the period 0-4? Inputs for quality ECD interventions. Human Sciences Research Council. https:// www.gtac.gov.za/Researchdocs/What $\% 20$ makes $\% 20 a \% 20$ difference $\% 20$ to $\% 20$ childoutcomes\%20in\%20the\%20period\%200-4.pdf

Botha, A., Batchelor, J., Traxler, J., De Waard, I., \& Herselman, M. (2012). Towards a mobile learning curriculum framework. In P. Cunningham, \& M. Cunningham (Eds.), IST-Africa 2012 conference proceedings. IIMC. https://itg.academia.edu/IgnatiaIngedeWaard/Papers/1645325/Towards a Mobile Curriculum Framework

Botha, A., \& Vosloo, S. (2009). Mobile learning: South African examples. Paper presented to Mobile Learning Institute Summit, Lusaka. https://www.slideshare.net/stevevosloo/mobile-learning-south-african-examples 
Chee, K. N., Yahaya, N., Ibrahim, N. H., \& Noor Hassan, M. (2017). Review of mobile learning trends 2010-2015: A meta-analysis. Educational Technology E' Society, 20(2), 113-126. https://www.researchgate.net/publication/315696935 Review of Mobile Learning Trends 2010-2015 A Meta-Analysis

Conole, G. (2004). E-learning: The hype and the reality. Journal of Interactive Media in Education, 12, 1-18. https://doi.org/10.5334/2004-12

Danaher, P., Gururajan, R., \& Hafeez-Baig, A. (2009). Transforming the practice of mobile learning: Promoting pedagogical innovation through education principles and strategies that work. In D. Parson, \& H. Rvu (Eds.), Innovative and mobile learning: Techniques and technologies (pp. 21-46). IGI Global.

https://doi.org/10.4018/978-1-60566-062-2.ch002

Department of Basic Education (DBE). (2018). Professional development framework for digital learning.Government of South Africa. https://www.education.gov.za/ Portals/0/Documents/Publications/Digita1\%20Learning\%20Framework.pdf?ver=2018-07-09-101748-95

DBE, Department of Social Development (DSD), \& UNICEF. (2011). Tracking public expenditure and assessing service quality in early childhood development in South Africa. https://www.unicef.org/southafrica/media/1736/file/ZAF-tracking-public-expenditure-and-assessing-service-quality-in-early-childhood-development-2011.pdf

Department of Social Development (DSD). (2006). Guidelines for early childhood development services. Government of South Africa. https://www.gov.za/sites/default/files/ gcis document/201409/childhooddev0.pdf

Department of Social Development (DSD). (2014). Audit of early childhood development (ECD) centres: National report. Government of South Africa. https://ilifalabantwana.co.za/wp-content/uploads/2015/08/ECDAuditNationalReport20140731ReviewedFINALVersionES11.pdf

Ebner, M., \& Grimus M. (2013). M-learning in Sub Saharan Africa context. What is it about? Paper presented at the World Conference on Educational Media and Technology, 24-28 June, Victoria, BC, Canada. https://www.researchgate.net/publication/283727687 M-Learning in Sub Saharan Africa Context- What is it about

Eun, B. (2008). Making connections: Grounding professional development in the developmental theories of Vygotsky. The Teacher Educator, 43(2), 134-155.

https://doi.org/10.1080/08878730701838934

Feza, N. (2014). Inequities and lack of professionalisation of early childhood development practice hinder opportunities for mathematics stimulation and realisation of South African policy on quality education for all. International Journal of Inclusive Education, 18(9), 888-902. https://doi.org/10.1080/13603116.2013.855266

Hall, K. (2019). Income poverty, unemployment and social grants. In M. Shung-King, L. Lake, D. Sanders, \& M. Hendricks (Eds.), South African child gauge 2019 (pp. 222227). Children's Institute, University of Cape Town. http://childrencount.uct.ac.za/ uploads/publications/ChildGauge\%202019 final.pdf 
Herrington, J., \& Oliver, R. (2001). A beginner's guide to e-learning and e-teaching in bigher education. Centre for Research in Information Technology and Communications, Edith Cowan University, Western Australia. http://researchrepository.murdoch. edu.au/1903/

Herselman, M., \& Botha, A. (Eds.). (2014). Designing and implementing an information communication technology for rural education development (ICT4RED) initiative in a resource constrain [ed] environment: $N$ ciba school district, Eastern Cape, South Africa. CSIR Meraka. http://hdl.handle.net/10204/8094

Isaacs, S. (2012). Mobile learning for teachers in Africa and the Middle East. UNESCO Working Paper Series on Mobile Learning. http://www.schoolnet.org.za/sharing/mobile_learning_AME.pdf

Isaacs, S., Roberts, N., \& Spencer-Smith, G. (2019). Learning with mobile devices: A comparison of four mobile learning pilots in Africa. South African Journal of Education, 39(3), 1-13. https://doi.org/10.15700/saje.v39n3a1656

Isaacs, S., Roberts, N., Spencer-Smith, G., \& Brink, S. (2019). Learning through play in Grade R classrooms: Measuring practitioners' confidence, knowledge and practice. South African Journal of Childhood Education, 9(1), 1-11.

https://doi.org/10.4102/sajce.v9i1.704

Kearney, M., Schuck, S., Burden, K., \& Aubusson, P. (2012). Viewing mobile learning from a pedagogical perspective. Research in Learning Technology, 20(1), 1-17.

https://doi.org/10.3402/rlt.v20i0.14406

Kelly, L. J. (2007). The interrelationships between adult museum visitors' learning identities and their museum experiences. PhD thesis, University of Technology, Sydney.

Klopfer, E., Squire, K., \& Jenkins, H. (2002). Environmental detectives: PDAs as a window into a virtual simulated world. In IEEE (Ed.), Proceedings of IEEE International Workshop on Wireless and Mobile Technologies in Education (WMTE'02) (pp. 95-98). https://doi.org/10.1109/WMTE.2002.1039227

Koole, M. (2009). A model for framing mobile learning. In M. Ally (Ed.), Mobile learning: Transforming the delivery of education and training (pp. 26-50). Athabasca University Press.

Laurillard, D. (2002). Rethinking university teaching: A conversational framework for the effective use of learning technologies (2nd ed.). Routledge Falmer. https://doi.org/10.4324/9780203304846

May, J., Witten, C., Lake, L., \& Skelton, A. (2020). The slow violence of malnutrition. In J. May, C. Witten, \& L. Lake (Eds.), South African child gauge 2020 (pp. 24-45). Children's Institute, University of Cape Town.

National Planning Commission (NPC). (2012). National development plan 2030: Our future - make it work. Government of South Africa. https://www.gov.za/sites/default/files/ gcis_document/201409/ndp-2030-our-future-make-it-workr.pdf

Nedungadi, P., \& Raman, R. (2012). A new approach to personalization: Integrating e-learning and m-learning. Educational Technology Research and Development, 60(4), 659678. https://doi.org/10.1007/s11423-012-9250-9 
Organisation for Economic Co-operation and Development (OECD). (2017). The OECD bandbook for innovative learning environments, educational research and innovation. OECD Publishing.

Pouezevara, S., \& Strigel, C. (2012). Mobile learning and numeracy: Filling gaps and expanding opportunities for early grade learning. RTI International. https://www.rti.org/pubs/ mobilelearningnumeracy rti final $17 \mathrm{dec} 12$ edit.pdf

Republic of South Africa (RSA). (2015). National Integrated Early Childhood Development Policy. https://www.gov.za/sites/default/files/gcis_document/201610/national-integrated-ecd-policy-web-version-final-01-08-2016a.pdf

Roberts, N., \& Spencer-Smith, G. (2019). A modified analytical framework for describing m-learning (as applied to early grade Mathematics). South African Journal of Childhood Education, 9(1), 1-11. https://doi.org/10.4102/sajce.v9i1.532

Shabani, K. (2016). Applications of Vygotsky's socio-cultural approach for teachers' professional development. Cogent Education, 3(1), 1-10.

https://doi.org/10.1080/2331186X.2016.1252177

Statistics South Africa (Stats SA). (2016). Education Series IV: Early Childhood Development in South Africa 2016. Government of South Africa. http://www.statssa.gov.za/publications/92-01-04/92-01-042016.pdf

Thorogood, C., Goeiman, H., Berry, L., \& Lake, L. (2020). Food and nutrition security for the preschool child: Enhancing early childhood development. In J. May, C. Witten, \& L. Lake (Eds.), South African child gauge 2020 (pp. 96-110). Children's Institute, University of Cape Town.

Traxler, J. (2007). Defining, discussing and evaluating mobile learning: The moving finger writes and having writ .... The International Review of Research in Open and Distributed Learning, 8(2), 1-12. https://doi.org/10.19173/irrodl.v8i2.346

Trucano, M. (2016). SABER-ICT Framework Paper for Policy Analysis: Documenting national educational technology policies around the world and their evolution over time. World Bank. https://doi.org/10.1596/26107

Vygotsky, L. S. (1978). Mind in society: The development of higher psychological processes. Harvard University Press.

Wills, G., \& Kika-Mistry, J. (2021). Early childhood development in South Africa during the COVID-19 pandemic: Evidence from National Income Dynamics Study - Coronavirus Rapid Mobile Survey (NIDS-CRAM): Waves 2-5. https://cramsurvey.org/wp-content/uploads/2021/07/14.-Wills-G- -Kika-Mistry-J.-2021-Early-ChildhoodDevelopment-in-South-Africa-during-the-n-COVID-19-pandemic-Evidencefrom-NIDS-CRAM-Waves-2-5.pdf

World Bank. (2018). World development report: Learning to realize education's promise. https://doi.org/10.1596/978-1-4648-1096-1 